\title{
PENGARUH STRATEGI PEMBELAJARAN BERBASIS MEDIA INTERAKTIF DAN GAYA BERPIKIR TERHADAP KOMPETENSI TEKNOLOGI PENGOLAHAN HASIL PERTANIAN
}

\author{
Bettysulastri Manullang \\ Guru SMK Negeri Berastagi, Sumatera Utara \\ Betty_manullang@gmail.com
}

\begin{abstract}
Abstrak: Penelitian ini bertujuan mengetahui: (1) Hasil belajar siswa yang dibelajarkan dengan menggunakan media pembelajaran interaktif model tutorial dengan siswa yang dibelajarkan dengan menggunakan pembelajaran interaktif model latihan dan praktik, (2) Hasil belajar TPHP siswa yang memiliki gaya berpikir sekuensial abstrak lebih tinggi dibandingkan dengan siswa yang memiliki gaya berpikir sekuensial konkret dan (3) Interaksi antara media pembelajaran interaktif dan gaya berpikir terhadap hasil belajar TPHP. Populasi dalam penelitian ini adalah seluruh kelas X jurusan Teknologi Pengolahan Hasil Pertanian SMK Negeri 1 Berastagi berjumlah 96 orang. Sampel Penelitian terdiri dari 32 siswa penggunaan media interaktif model tutorial dan 32 siswa penggunaan media interaktif model latihan dan praktik. Teknik penarikan sampel dilakukan dengan purposive sampling. Instrumen pengukuran untuk mengukur hasil belajar digunakan tes berbentuk pilihan ganda dengan 4 pilihan jawaban. Untuk menjaring data gaya berpikir siswa digunakan angket yang telah diuji kevalidannya. Metode penelitian menggunakan kuasi eksperimen dengan desain faktorial 2 × 2 . Teknik analisis data Anava dua jalur. Hasil penelitian menunjukkan bahwa (1) Hasil belajar TPHP siswa yang dibelajarkan dengan penggunaan media interaktif latihan dan praktik lebih tinggi dari hasil belajar siswa yang dibelajarkan dengan menggunakan media interaktif tutorial, (2) Hasil belajar TPHP siswa yang memiliki gaya berpikir sekuensial abstrak, (3) Interaksi antara pembelajaran menggunakan media interaktif dengan gaya berpikir siswa terhadap hasil belajar TPHP.
\end{abstract}

Kata Kunci: media pembelajaran interaktif, tutorial, latihan dan praktik, gaya belajar, teknologi pengolahan hasil pertanian

\begin{abstract}
This study aims to find out: (1) Student learning outcomes that are learned by using interactive learning media tutorial model with students who are taught by using interactive learning model of practice and practice, (2) TPHP learning result of students who have abstract sequential thinking style is higher compared with students who have concrete sequential thinking styles and (3) Interaction between interactive learning media and thinking style on TPHP learning outcomes. Population in this research is all class of $X$ Department of Agricultural Product Processing Technology SMK Negeri 1 Berastagi amounted to 96 people. The study sample consisted of 32 students using interactive media tutorial model and 32 students using interactive media model of practice and practice. Sampling technique is done by purposive sampling. Measurement instruments to measure learning outcomes were used multiple choice test with 4 answer choices. To collect data of students' thinking style used questionnaire that has been tested its validity. The research method used quasi experiment with $2 \times 2$ factorial design. Two way data analysis Anava technique. The results showed that (1) TPHP learning outcomes of students who were taught by the use of interactive media exercises and practices higher than the results of student learning are taught by using interactive tutorial media, (2) TPHP learning results of students who have abstract sequential thinking style, (3) ) Interaction between learning using interactive media with student's thinking style to TPHP learning result.
\end{abstract}

Keywords: interactive learning media, tutorial, practice and practice, learning style, agricultural processing technology

\section{PENDAHULUAN}

Teknologi informasi merupakan salah satu solusi bagi beragam masalah pendidikan.
Secara khusus pemanfaatan teknologi informasi

dalam pembelajaran dipercaya akan: (1)

Meningkatkan kualitas pembelajaran, (2) 
Mengembangkan keterampilan teknologi informasi yang diperlukan oleh siswa ketika menyelesaikan tugas, (3) Memperluas akses terhadap pendidikan dan pembelajaran, (4) Menjawab keharusan berpartisipasi dalam teknologi informasi, (5) Mengurangi biaya pendidikan, (6) Meningkatkan rasio biayamanfaat dalam pendidikan.

Sekolah Menengah Kejuruan Negeri (SMK) 1 Berastagi adalah salah satu sekolah menengah kejuruan yang menjadi pilihan utama sebahagian besar siswa SMP yang akan melanjutkan jenjang pendidikan menengah kejuruan di Kecamatan Berastagi Kabupaten Karo. Hal ini terlihat dari banyaknya siswa lulusan SMP sederajat yang mendaftar ke sekolah ini dengan rata-rata pendaftar hampir sekitar 500 orang siswa setiap tahunnya dari seluruh Kecamatan Berastagi. Namun dari hasil seleksi yang dilakukan oleh pihak sekolah berdasarkan kriteria dan syarat yang harus dipenuhi oleh calon siswa berdasarkan daya tamping sekolah, maka rata-rata tiap tahunnya hanya diterima sekitar 300 orang siswa 4 program keahlian yang ada di sekolah menengah kejuruan ini. Adapun bidang program keahlian di SMK Negeri 1 Berastagi meliputi: (1) Kria Kayu, (2) Kria Tekstil, (3) Akomodasi Perhotelan, (4) Teknologi Pengolahan Hasil Pertanian dan Pangan (sumber: data keadaan siswa SMKN 1 Berastagi).

Mata pelajaran produktif pengolahan hasil pertanian merupakan mata pelajaran yang membutuhkan pemahaman konsep, kemampuan berpikir logis, kritis, analisis, kognitif serta psikomotor. Dengan gaya berpikir seperti inilah munculnya generasi penerus yang berdedikasi tinggi, unggul, handal, bertanggung jawab dan berprestasi. Mata pelajaran produktif ini merupakan salah satu mata pelajaran pokok yang diajarkan di SMK dan merupakan salah satu mata pelajaran yang diuji dalam Ujian Nasional. Adapun tujuan pembelajaran produktif pengolahan hasil pertanian secara umum adalah untuk melatih daya pikir siswa, serta kreatifitasnya dalam mengembangkan produk hasil pertanian agar produk hasil pertanian tidak cepat rusak dan meningkat daya produksinya sehingga harga jualnya juga meningkat, dengan demikian penghasilan produsen meningkat. Setelah mengolah hasil pertanian, siswa juga diharapkan mampu untuk memeriksa kadar air bahan, sehingga dapat diperkirakan berapa lama bahan tahan disimpan setelah diolah. Selain itu juga diperiksa kadar lemaknya, kadar abu, kadar protein untuk mengetahui angka kecukupan gizi setelah dilakukan pengolahan.

Dick and Carey (2001: 13) menjelaskan bahwa strategi pembelajaran merupakan penjelasan komponen-komponen umum dari suatu set bahan pembelajaran dan prosedurprosedur yang akan digunakan bersama bahanbahan tersebut untuk menghasilkan hasil belajar tertentu pada siswa. Beliau juga menjelaskan bahwa strategi pembelajaran terdiri atas lima komponen utama yaitu: (1) Aktivitas pembelajaran pendahuluan, (2) Penyampaian informasi, (3) partisipasi siswa, (4) Tes, (5) Kegiatan lanjutan. Sedangkan Suparman(1997) mendefinisikan strategi pembelajaran sebagai perpaduan dari (1) Urutan kegiatan instruksional, (2) Cara pengorganisasian pengajaran dan siswa, (3) Peralatan dan bahan, (4) Waktu yang digunakan dalam proses instruksional. Definisi strategi pembelajaran di atas pada dasarnya lebih menekankan pada aspek-aspek komponen dan prosedur pengajaran.

Hamdani (2011: 19) menyatakan ada 3 variabel yang harus diperhatikan dalam kegiatan pembelajaran yaitu: (1) kondisi pengajaran yaitu faktor yang mempengaruhi efek penggunaan metode pengajaran dalam upaya meningkatkan hasil pengajaran, (2) metode pengajaran yaitu cara-cara yang berbeda untuki mencapai hasil pengajaran yang berbeda di bawah kondisi yang berbeda, (3) hasil pengajran yaitu semua efek yang dapat dijadikan sebagai indikator tentang nilai dari penggunaan metode pengajaran di bawah kondisi yang berbeda.

Menurut Arifin dan Setiawan (2012: 56) bahwa pengertian strategi dalam kaitannya dengan pembelajaran adalah siasat atau kiat yang sengaja direncanakan oleh guru, berkenaan dengan segala persiapan pembelajaran agar pelaksanaan pembelajaran berjalan dengan lancar dan tujuannya yang berupa hasil belajar bisa tercapai optimal. Strategi pembelajaran merupakan rencana tindakan termasuk penggunaan metode dan pemanfaatan berbagai sumber daya atau kekuatan dalam pembelajaran yang disusun untuk mencapai tujuan pembelajaran.

Siregar (2010: 75) menjelaskan bahwa pendekatan inovatif dalam strategi pembelajaran diperlukan untuk mengaktifkan keterlibatan siswa secara mandiri dalam proses 
pembelajaran, melalui kegiatan pembelajaran yang berorientasi pada proses penemuan (discovery) dan pencarian (inquiry).

Frankel dalam Patmonodewo (2001: 25) mendefinisikan berpikir sebagai pembentukan ide-ide, reorganisasi dan pengalaman-pengalaman seseorang dan pengorganisasian informasi-informasi ke dalam bentuk yang khas. Ahmadi (2003: 20) mendefinisikan berpikir sebagai aktivitas psikis yang potensial, dan terjadi apabila seseorang menyimpan problem (masalah) yang harus dipecahkan.

Ahmadi (2003: 55) menggolongkan jenis berpikir ke dalam lima kategori yaitu: (1) Berpikir dengan pengalaman yang artinya berpikir dengan pengalaman sebagai indikator dalam memecahkan masalah, (2) Berpikir presentatif yang artinya berpikir dengan menggunakan ingatan dan tanggapan, (3) Berpikir kreatif, yaitu berpikir untuk menghasilkan sesuatu yang baru dengan kata lain menghasilkan penemuan-penemuan baru, (4) Berpikir reproduktif, yaitu berpikir sesuatu untuk kegunaan mencocokkannya dengan sesuatu yang telah dipikirkan sebelumnya, (5) Berpikir rasional yaitu berpikir dengan menggunakan akal sehat untuk memecahkan masalah.

Dengan demikian, dalam berpikir itu seseorang harus dapat menghubungkan pengertian yang satu dengan yang lainnya dalam rangka mendapatkan pemecahan yang dihadapinya. Pandangan ini sejalan dengan pandangan yang dikemukakan Sagala (2003: 124) bahwa sesungguhnya berpikir itu sebagai proses menentukan hubungan-hubungan secara bermakna antara aspek-aspek dari pengetahuan yang diperoleh manusia. Selanjutnya Albrecht (2003: 57) berpandangan bahwa berpikir merupakan proses menyikapi sebagai pengetahuan, baik pengetahuan berupa bentuk, suara atau rasa yang berasal dari dalam (ingatan). Pandangan ini juga relevan dengan yang dikemukakan oleh Award (2004: 55) bahwa berpikir merupakan proses pengklasifikasian, perbandingan dan penilaian terhadap pengetahuan berdasarkan kepercayaan, keyakinan dan nilai-nilai yang tertata, lalu berubah menjadi bentuk strategi yang menghasilkan pengungkapan secara bahasa atau tindakan.

Dalam keseluruhan proses pendidikan di sekolah kegiatan belajar merupakan kegiatan yang paling pokok. Ini berarti berhasil tidaknya pencapaian tujuan pendidikan banyak tergantung pada bagaimana proses belajar yang dialami siswa selaku peserta didik. Menurut Winkel (1996: 53) belajar adalah suatu aktivitas mental atau psikis yang berlangsung dalam interaksi aktif dengan lingkungan yang menghasilkan sejumlah perubahan dalam pengetahuan pemahaman,keterampilan dan nilai-sikap. Perubahan itu bersifat relatif konstan dan berbekas.

Belajar adalah suatu proses mental dan emosional atau proses berpikir dan merasakan. Menurut Pidarta (1997: 123) menekankan bahwa belajar adalah perubahan perilaku yang relatif permanen sebagai hasil pengalaman dan bisa melaksanakannya pada pengetahuan lain serta mampu mengkomunikasikannya kepada orang lain.

Pada hakikatnya, belajar adalah proses perubahan perilaku berkat pengalaman dan latihan, yang mana tujuan dari kegiatan adalah perubahan tingkah laku, baik yang menyangkut pengetahuan, keterampilan maupun sikap, bahkan meliputi segenap aspek organism atau pribadi (Dahar, 2006 : 5). Dahar menambahkan bahwa belajar adalah sebagai suatu proses di mana suatu organisasi berubah perilakunya sebagai akibat pengalaman. Belajar menyangkut perubahan dalam suatu organisme.

Perubahan perilaku sebagai perbuatan belajar sering disebut sebagai hasil belajar. Menurut Gagne (1988: 36) bahwa hasil belajar adalah kemampuan-kemampuan yang dimiliki siswa sebagai akibat perbuatan belajar dan diamati melalui pemahaman siswa (learner's performance). Pendapat Dick and Raiser (1989: 201) tentang hasil belajar adalah bahwa hasil belajar itu adalah kemampuan-kemampuan yang dimiliki siswa sebagai hasil kegiatan pembelajaran, mereka mengemukakan hasil belajar dapat dibedakan atas empat macam, yaitu: pengetahuan, keterampilan, intelektual, keterampilan motorik dan sikap. Lebih lanjut Bloom (1956: 204) mengemukakan bahwa hasil belajar yang menunjukkan proses perkembangan kemampuan dalam diri siswa dapat dikategorikan dalam tiga ranah, yaitu: kognitif, afektif dan psikomotorik.

Menurut Hamdani (2011: 17) bahan belajar terjadi ketika interaksi antara individu dan lingkungan, baik lingkungan fisik maupun social. Seseorang dapat dikatakan telah belajar sesuatu dalam dirinya telah terjadi perubahan, akan tetapi tidak semua perubahan terjadi. Jadi hasil belajar merupakan pencapaian tujuan 
belajar dan hasil belajar sebagai produk dari proses belajar. Selain ranah afektif dan psikomotorik, hasil belajar yang perlu diperhatikan adalah dalam ranah kognitif.

Dari beberapa pendapat yang telah dikemukakan di atas, maka dapat dinyatakan bahwa yang dikatakan hasil belajar adalah perubahan yang terjadi dalam individu yang terjadi karena sesuatu usaha, yaitu usaha belajar. Perubahan tingkah laku itu meliputi perubahan pengetahuan, perubahan sikap; dan perubahan keterampilan untuk mendapatkan hasil belajar atau mutu yang maksimal sesuai dengan yang dituntut pembelajaran sesuatu mata pelajaran.

Begitu juga halnya dalam upaya mencapai hasil belajar maksimal pada mata pelajaran produktif teknologi pengolahan hasil pertanian (TPHP). Untuk memahami hakikat hasil belajar produktif pengolahan hasil pertanian, maka perlu penjabaran mengenai hakikat belajar pengolahan hasil pertanian itu sendiri. Teknologi pengolahan hasil pertanian merupakan mata pelajaran produktif di SMK dan merupakan kegiatan manusia berupa pengetahuan, gagasan dan konsep yang terorganisasi tentang alam sekitarnya, yang diperoleh dari pengalaman melalui serangkaian proses ilmiah. Proses ini antara lain meliputi penyelidikan, penyusunan dan pengujian gagasan-gagasan.

Teknologi pengolahan hasil pertanian merupakan pengolahan hasil pertanian yang bertujuan untuk meningkatkan hasil pertanian dan memperpanjang daya simpan dengan cara mengurangi kandungan air yang terdapat pada hasil pertanian tersebut. Salah satu hal yang dilakukan untuk mengurangi kandungan air pada hasil pertanian adalah dengan cara pengeringan. Pengeringan merupakan metode tertua pengawetan bahan pangan. Pengeringan pangan berarti pemindahan air dengan sengaja dari bahan pangan. Selama pengeringan terjadi penguapan air pada bahan pangan (Dwiari, 2008: 61).

Frankel dalam Patmonodewo (2001: 25) mendefinisikan berpikir sebagai pembentukan ide-ide, reorganisasi dan pengalaman-pengalaman seseorang dan pengorganisasian informasi-informasi ke dalam bentuk yang khas. Ahmadi (2003: 20) mendefinisikan berpikir sebagai aktivitas psikis yang potensial, dan terjadi apabila seseorang menyimpan problem (masalah) yang harus dipecahkan.
Ahmadi (2003: 55) menggolongkan jenis berpikir ke dalam lima kategori yaitu: (1) Berpikir dengan pengalaman yang artinya berpikir dengan pengalaman sebagai indikator dalam memecahkan masalah, (2) Berpikir presentatif yang artinya berpikir dengan menggunakan ingatan dan tanggapan, (3) Berpikir kreatif, yaitu berpikir untuk menghasilkan sesuatu yang baru dengan kata lain menghasilkan penemuan-penemuan baru, (4) Berpikir reproduktif, yaitu berpikir sesuatu untuk kegunaan mencocokkannya dengan sesuatu yang telah dipikirkan sebelumnya, (5) Berpikir rasional yaitu berpikir dengan menggunakan akal sehat untuk memecahkan masalah.

Albrecht (2004: 37) menyatakan bahwa aktivitas favorit orang yang pemikir sekuensial abstrak adalah membaca, menulis dengan bebas, menggunakan istilah abstrak, senang akan perhitungan-perhitungan seperti matematika, serta konsep dan teori. Selanjutnya Muhibbin (2004: 79) juga menyatakan pendapatnya bahwa pemikir sekeunsial abstrak dalam mengolah informasi cendering menggunakan peranan akal yang kuat (logika) di samping penguasaan atas prinsip, konsep dan generalisasi.Menurut beliau pemikir sekuensial abstrak ini cocok dalam belajar matematika, fisika, kimia, kosmologi, astronomi dan yang sejenisnya. Begitu pula dengan Dryden dan Jeanette (2001: 95) menyatakan bahwa pemikir sekuensial abstrak memiliki ciri-ciri antara lain: analisis, kritis, suka mencipta, personal, sistematis, penuh dengan perasaan, logis, pembaca dan suka berpikir abstrak yaitu berpikir rasional dan kritis.

Pemikir sekuensial konkret harus mengatur tugas-tugas menjadi proses tahap demi tahap dan berusaha keras untuk mendapatkan kesempurnaan pada setiap tahap. Mereka menyukai pengarahan dan prosedur khusus. Sesuai dengan pandangan di atas, De Porter Hernacki (2005 : 56) menyatakan bahwa pemikir sekuensial konkret dalam menerima informasi cenderung membutuhkan penjelasan dan tujuan yang menyeluruh dari suatu permasalahan.Orang seperti ini, dalam memperhatikan dan mengingat realitas dengan asosiasi visual secara teliti dan detail. Orang dengan pemikir sekuensial konkret mempunyai masalah untuk mengingat instruksi secara verbal kecuali jika ditulis dan sering sekali meminta bantuan orang lain untuk mengulanginya. Orang seperti ini sangat baik 
dalam membuat catatan-catatan dari informasi yang mereka terima.

Dryden dan Jeanette (2001: 85) berpendapat bahwa pemikir sekuensial konkret memiliki ciri-ciri antara lain: realistis, teratur, langsung pada permasalahan, praktis, tepat, perfeksionis, kerja keras, perencana, penghafal, mengharapkan arahan, suka berlatih dan selalu menuntaskan persoalan yang sedang terjadi. Tidak berbeda dengan pendapat tersebut, Gunawan (2004: 48) berpendapat bahwa orang sekuensial konkret dalam memahami sesuatu hal dengan cara tahap demi tahap, senang dengan bentuk yang detail. Semakin detail dan lengkap informasi yang mereka terima, semakin senang dan semakin baiklah pemahaman mereka.

Masalah penelitian ini dapat dirumuskan sebagai berikut: (1) Apakah kelompok siswa yang diajar dengan strategi pembelajaran berbasis media interaktif latihan dan praktik memperoleh hasil belajar produktif pengolahan hasil pertanian lebih tinggi dibanding kelompok siswa yang diajar dengan strategi pembelajaran berbasis media interaktif tutorial?; (2) Apakah kelompok siswa yang memiliki gaya berpikir sekuensial abstrak memperoleh hasil belajar produktif teknologi pengolahan hasil pertanian lebih tinggi dibanding kelompok siswa yang memiliki gaya berpikir sekuensial konkret?; dan (3) Apakah terdapat interaksi antara strategi pembelajaran berbasis media interaktif dan gaya berpikir dalam mempengaruhi hasil belajar siswa dalam mata pelajaran produktif teknologi pengolahan hasil pertanian?

\section{METODE}

Penelitian ini dilaksanakan di SMK Negeri 1 Berastagi yang beralamat di Jln. SMIK No.1 Berastagi. Populasi dalam penelitian ini adalah seluruh siswa kelas X SMK Negeri 1 Berastagi yang berjumlah 96 orang. Dimana jumlah siswa tersebut terdiri dari tiga kelas, dimana jumlah siswa tersebut terbagi dalam 3 kelas sebagai berikut: kelas TPHP 1 sebanyak 32 orang, TPHP 2 sebanyak 32 orang dan TPHP 3 sebanyak 32 orang. Teknik pengambilan sampel dalam penelitian cluster random sampling.

Metode penelitian yang digunakan adalah metode quasi-eksperimental design) atau metode eksperimental semu. Eksperimen dilakukan terhadap siswa dengan perlakuan menggunakan media pembelajaran dan tanpa menggunakan media pembelajaran. Pada masing-masing kelas eksperimen terdiri dari kelompok siswa yang memiliki gaya berpikir sekuensial abstrak dan gaya berpikir sekuensial konkret. Variabel-variabel tersebut selanjutnya dimasukkan di dalam desain penelitian sebagaimana pada Tabel 1 berikut.

Tabel 1. Desain Penelitian Faktorial 2 x 2

\begin{tabular}{|l|c|c|}
\hline \multicolumn{1}{|c|}{ Strategi Pembelajaran } & $\begin{array}{l}\text { Latihan dan } \\
\text { Praktik(A1) }\end{array}$ & Tutorial(A2) \\
Gaya Berpikir & A1 B1 & A2 B1 \\
\hline Sekuensial Abstrak (B1) & A1 B2 & A2 B2 \\
\hline Sekunsial Konkret (B2) &
\end{tabular}

Untuk menguji hipotesis penelitian digunakan teknik analisis data dengan analisis varian (ANAVA) dua jalur dengan taraf signifikan 0,05 (Sudjana,1994:23). Untuk menggunakan ANAVA dua jalur perlu dipenuhi beberapa syarat yaitu: (1) data yang digunakan harus berdistribusi normal, maka dilakukan uji normalitas dengan menggunakan uji Lilifors, (2) data harus memiliki varians populasi yang homogen maka dilakukan uji homogenitas varians dengan menggunakan uji F (Fisher) dan Bartlet. Untuk keperluan hipotesis maka perlu dirumuskan hipoteis statistik.

\section{Hipotesis Statistik} adalah

Hipotesis statistik yang akan diuji
Hipotesis Pertama: Ho1 : $\mu \mathrm{A} 1=\mu \mathrm{A} 2$

Ha1 : $\mu \mathrm{A} 1>\mu \mathrm{A} 2$

Hipotesis Kedua : $\mathrm{Ho} 2: \mu \mathrm{B} 1=\mu \mathrm{B} 2$ $\mathrm{Ha} 2: \quad \mu \mathrm{B} 1>\mu \mathrm{B} 2$

Hipotesis Ketiga : Ho3 : A x B =0 Ho3 : $\mathrm{A} \times \mathrm{B} \neq 0$

Keterangan:

$\mu \mathrm{A}_{1}=$ rata-rata hasil belajar TPHP kelompok siswa yang dibelajarkan dengan menggunakan media pembelajaran interaktif latihan dan praktik

$\mu \mathrm{A}_{2}=$ rata-rata hasil belajar TPHP kelompok siswa yang dibelajarkan dengan menggunakan media pembelajaran interaktif tutorial 
$\mu \mathrm{B}_{1}=$ rata-rata hasil belajar TPHP kelompok siswa yang memiliki gaya berpikir abstrak

$\mu \mathrm{B}_{2}=$ rata-rata hasil belajar TPHP kelompok siswa yang memiliki gaya berpikir konkret

$\mathrm{AxB}=$ Interaksi antara penggunaan media pembelajaran interaktif dengan gaya berpikir
Setelah pengujian hipotesis dilakukan maka dilakukan pengujian uji lanjut dengan menggunakan Uji Tukey, hal ini dilakukan karena jumlah n setiap sel sama.

\section{HASIL PENELITIAN}

Pengujian hipotesis dilakukan menggunakan teknik analisis varians (ANAVA). Untuk analisis varians, data yang diperlukan dapat dilihat pada Tabel 2 .

Tabel 2. Rangkuman Data Hasil Perhitungan Analisis Deskriptif

\begin{tabular}{|c|l|l|l|}
\hline Gaya Berpikir (B) & \multicolumn{2}{|c|}{ Media Pembelajaran Interaktif } & \multirow{2}{*}{ Total } \\
\cline { 2 - 3 } & \multicolumn{1}{|c|}{ Latihan \& Praktik (A1) } & \multicolumn{1}{|c|}{ Tutorial (A2) } & \\
\hline $\begin{array}{c}\text { Sekuensial Abstrak } \\
\text { (B1) }\end{array}$ & $\mathrm{N}=16$ & $\mathrm{~N}=16$ & $\mathrm{~N}=32$ \\
& $\mathrm{X}=79,75$ & $\mathrm{X}=60,50$ & $\mathrm{X}=70,13$ \\
& $\sum \mathrm{X}^{2}=95,932$ & $\sum \mathrm{X}^{2}=59,058$ & $\sum \mathrm{X}^{2}=154,990$ \\
\hline Sekuensial & $\mathrm{N}=16$ & $\mathrm{~N}=16$ & $\mathrm{~N}=32$ \\
Konkret (B2) & $\overline{\mathrm{X}}=62,13$ & $\mathrm{X}=72,50$ & $\mathrm{X}=67,13$ \\
& $\sum \mathrm{X}^{2}=62,130$ & $\sum \mathrm{X}^{2}=90,428$ & $\sum \mathrm{X}^{2}=152,558$ \\
\hline Total & $\mathrm{N}=32$ & $\mathrm{~N}=32$ & $\mathrm{~N}=64$ \\
& $\overline{\mathrm{X}}=70,94$ & $\mathrm{X}=66,50$ & $\overline{\mathrm{X}}=68,72$ \\
& $\sum \mathrm{X}^{2}=158,062$ & $\sum \mathrm{X}^{2}=149,758$ & $\sum \mathrm{X}^{2}=307,548$ \\
\hline
\end{tabular}

Hasil pehritungan ANAVA seperti yang ditunjukkan dalam Tabel 3, yaitu rangkuman analisis faktorial $2 \times 2$. Setelah data Tabel 20 diolah dengan Anava dua jalur factorial 2 × 2, maka diperoleh hasil analisis seperti ditunjukkan pada Tabel 3.

Tabel 3. Rangkuman Analisis Faktorial 2 x 2

\begin{tabular}{|l|c|c|c|c|c|c|}
\hline Sumber Varians & JK & DK & RJK & Fhitung & Ftabel & Kesimpulan \\
\hline MPI & 315,06 & 1 & 315,06 & 10,98 & 3,82 & Signifikan \\
Gaya Berpikir & 126,56 & 1 & 126,56 & 4,41 & 3,82 & Signifikan \\
Interaksi & $3.130,57$ & 1 & $3.130,57$ & 109,08 & 3,82 & Signifikan \\
\hline Galat & 945,56 & 61 & 16,88 & & & \\
\hline Total & $5.322,94$ & 62 & & & & \\
\hline
\end{tabular}

Berdasarkan rangkuman di atas maka akan dirinci pengujian hipotesis sebagai berikut:

\section{Hipotesis Pertama}

Pengujian hipotesis pertama yang menyatakan hasil belajar TPHP siswa yang dibelajarkan dengan MPI latihan \& praktik, lebih tinggi daripada hasil belajar siswa yang diajarkan dengan MPI tutorial, hipotesis statistiknya adalah:

$$
\text { Ho : } \mu \mathrm{A}_{1}=\mu \mathrm{A}_{2} \quad \text { Ha }: \mu \mathrm{A}_{1}>\mu \mathrm{A}_{2}
$$

Pernyataan hipotesis tersebut adalah:

Ho = Rata-rata hasil belajar TPHP kelompok siswa yang dibelajarkan dengan menggunakan media pembelajaran interaktif latihan \& praktik atau sama dengan rata-rata hasil belajar TPHP siswa yang dibelajarkan dengan MPI Tutorial
$\mathrm{Ha}=$ Siswa yang dibelajarkan dengan menggunakan MPI latihan \& praktik memperoleh hasil belajar TPHP lebih tinggi daripada siswa yang dibelajarkan dengan MPI Tutorial

Berdasarkan perhitungan ANAVA factorial $2 \times 2$ diperoleh $\mathrm{F}_{\text {hitung }}=10,98$ sedangkan nilai $\mathrm{F}_{\text {tabel }}=3,82$ untuk dk $(1,62)$ dan taraf nyata $\alpha=0,05$. Ternyata nilai $F_{\text {hitung }}>$ $\mathrm{F}_{\text {tabel }}$ sehingga pengujian hipotesis menolak Ho dan menerima Ha. Dengan demikian dapat ditarik kesimpulan bahwa hasil belajar TPHP siswa yang dibelajarkan dengan MPI latihan \& praktik lebih tinggi dibanding dengan MPI tutorial teruji kebenarannya secara empirik.

\section{Hipotesis Kedua}

Pengujian hipotesis pertama yang menyatakan: hasil belajar TPHP siswa yang memiliki gaya berpikir abstrak, lebih tinggi 
daripada hasil belajar siswa yang memiliki gaya berpikir konkret, hipotesis statistiknya adalah: Ho: $\mu \mathrm{B}_{1}=\mu \mathrm{B}_{2}$

Pernyataan hipotesis tersebut adalah:

Ho = Siswa yang memiliki gaya berpikir abstrak memperoleh rata-rata hasil belajar TPHP lebih rendah atau sama dengan siswa yang memiliki gaya berpikir konkret

$\mathrm{Ha}=$ Siswa yang memiliki gaya berpikir abstrak memperoleh nilai hasil belajar TPHP lebih tinggi daripada siswa yang memiliki gaya berpikir konkret

Berdasarkan perhitungan ANAVA

faktorial $2 \times 1$ diperoleh $F_{\text {hitung }}=4,17$ sedangkan nilai $\mathrm{F}_{\text {tabel }}=3,82$ untuk dk $(1,62)$ dan taraf nyata $\alpha=0,05$. Ternyata nilai $F_{\text {hitung }}>F_{\text {tabel }}$ sehingga pengujian hipotesis menolak Ho dan menerima Ha. Dengan demikian dapat ditarik kesimpulan bahwa hasil belajar TPHP siswa yang memiliki gaya berpikir abstrak lebih tinggi dibanding siswa yang memiliki gaya berpikir konkret teruji kebenarannya secara empirik.

\section{Hipotesis Ketiga}

Pengujian hipotesis ketiga yaitu: terdapat interaksi antara MPI dan gaya berpikir dalam meningkatkan hasil belajar TPHP

Ho : A x B Ha : A x B $\neq$

Pernyataan hipotesis tersebut adalah :

Ho = Tidak terdapat interaksi antara MPI dan gaya berpikir terhadap hasil belajar TPHP siswa

$\mathrm{Ha}=$ Terdapat interaksi antara MPI dan gaya berpikir terhadap hasil belajar TPHP

Siswa

Berdasarkan perhitungan ANAVA faktorial $2 \times 2$ diperoleh $F_{\text {hitung }}=109,98$ sedangkan nilai $\mathrm{F}_{\text {tabel }}=3,82$ untuk dk $(1,62)$ dan taraf nyata $\alpha=0,05$. Ternyata nilai $F_{\text {hitung }}>F_{\text {tabel }}$ sehingga pengujian hipotesis menolak Ho dan menerima $\mathrm{Ha}>$ Dengan demikian dapat ditarik kesimpulan bahwa terdapat interaksi antara MPI dan gaya berpikir dalam meningkatkan hasil belajar TPHP siswa teruji kebenarannya secara empirik.

Dengan demikian untuk melihat perbandingan interaksi antara MPI dan gaya berpikir terhadap hasil belajar TPHP,maka dilakukan uji lanjut dengan uji Tuckey. Perhitungan untuk uji Tuckey dapat dilihat pada lampiran 9 halaman 164 . Rangkuman hasil perhitungan Uji Tuckey dapat dilihat pada Tabel 4.

Tabel 4. Rangkuman Hasil Uji Tukey

\begin{tabular}{|c|c|c|}
\hline No & Kelompok & Q $_{\text {hitung }}$ \\
\hline 1. & A1B1 dengan A2B1 & 13,29 \\
\hline 2. & A1B1 dengan A1B2 & 12,00 \\
\hline 3. & A1B1 dengan A2B2 & 1,79 \\
\hline 4. & A2B1 dengan A1B2 & 1,29 \\
\hline 5. & A2B1 dengan A2B2 & 11,51 \\
\hline 6. & A2B2 dengan A1B2 & 10,21 \\
\hline
\end{tabular}

Dari hasil uji Tuckey diperoleh kesimpulan yaitu:

1. Rata-rata hasil belajar TPHP siswa yang dibelajarkan dengan MPI latihan dan praktik dengan rata-rata hasil belajar TPHP yang dibelajarkan dengan menggunakan MPI tutorial dengan menghasilkan Qhitung sebesar 13,29. Dibanding dengan nilai $Q_{\text {tabel }}$ sebesar 2,15 dengan demikian $\mathrm{Q}_{\text {hitung }}>\mathrm{Q}_{\text {tabel. }}$. Ini berarti terdapat perbedaan hasil belajar TPHP antara siswa yang dibelajarkan dengan menggunakan MPI latihan dan praktik dengan siswa yang dibelajarkan dengan MPI tutorial.

2. Rata-rata hasil belajar TPHP siswa yang dibelajarkan dengan MPI latihan dan praktik dengan gaya berpikir sekuensial abstrak dengan sekuensial konkret tidak menunjukkan perbedaan. Hasil perhitungan Qhitung sebesar 12,00 dan nilai $Q_{\text {tabel }}$ sebesar 2,15 , dengan demikian $\mathrm{Q}_{\text {hitung }}<\mathrm{Q}_{\text {tabel. }}$. Ini berarti tidak terdapat perbedaan hasil belajar TPHP antara siswa yang memiliki gaya berpikir sekuensial abstrak dengan siswa yang memiliki gaya berpikir sekuensial konkret.

3. Rata-rata hasil belajar TPHP siswa yang dibelajarkan dengan MPI latihan dan praktik dengan siswa yang memiliki gaya berpikir sekuensial abstrak dibandingkan dengan hasil belajar TPHP siswa yang dibelajarkan dengan menggunakan MPI tutorial dengan siswa yang memiliki gaya berpikir konkret menunjukkan perbedaan yang tidak signifikan. Hasil perhitungan berdasarkan gaya berpikir sekuensial abstrak lebih tinggi dibandingkan dengan rata-rata hasil TPHP siswa yang dibelajarkan dengan MPI tutorial berdasarkan gaya berpikir sekuensial konkret. Hasil perhitungan $\mathrm{Q}_{\text {hitung }}$ sebesar 1,79 dan nilai $Q_{\text {tabel }}$ sebesar 2,15 dengan demikian $\mathrm{Q}_{\text {hitung }}<\mathrm{Q}_{\text {tabel }}$.

4. Rata-rata hasil belajar TPHP siswa yang dibelajarkan dengan MPI latihan dan praktik dengan siswa yang memiliki gaya berpikir sekuensial konkret dengan rata-rata hasil belajar TPHP yang dibelajarkan dengan MPI 
tutorial dengan siswa yang memiliki gaya berpikir sekuensial abstrak menghasilkan nilai $Q_{\text {hitung }}$ sebesar 1,29. Dibanding dengan nilai $Q_{\text {tabel }}$ sebesar 2,15 dengan demikian $\mathrm{Q}_{\text {hitung }}>_{\text {Qtabel. }}$ Ini berarti terdapat perbedaan hasil belajar TPHP antara siswa yang dibelajarkan dengan menggunakan MPI latihan dan praktik dengan siswa yang memiliki gaya berpikir sekuensial konkret dengan siswa yang dibelajarkan menggunakan MPI tutorial dengan gaya berpikir sekuensial abstrak.

5. Rata-rata hasil belajar TPHP siswa yang dibelajarkan dengan MPI latihan dan praktik dengan siswa yang dibelajarkan menggunakan MPI tutorial dengan siswa yang memiliki gaya berpikir sekuensial konkret menghasilkan nilai $Q_{\text {hitung }}$ sebesar 11,51. Dibanding dengan nilai $\mathrm{Q}_{\text {tabel }} 2,15$ dengan demikian $\mathrm{Q}_{\text {hitung }}>\mathrm{Q}_{\text {tabel. }}$ Ini berarti terdapat perbedaan hasil belajar TPHP antara siswa yang dibelajarkan dengan menggunakan MPI latihan dan praktik $\mathrm{Y}$ dengan siswa yang dibelajarkan dengan MPI tutorial dengan siswa yang memiliki gaya berpikir sekuensial konkret.

6. Rata-rata hasil belajar TPHP yang dibelajarkan dengan menggunakan MPI tutorial dengan siswa yang memiliki gaya berpikir sekuensial abstrak dan gaya berpikir sekuensial konkret menghasilkan nilai $\mathrm{Q}_{\text {hitung }}$ sebesar 10,21 Dibanding dengan nilai Qtabel sebesar 2,15 dengan demikian $\mathrm{Q}_{\text {hitung }}>\mathrm{Q}_{\text {tabel }}$. Ini berarti terdapat perbedaan hasil belajar TPHP antara siswa yang dibelajarkan dengan menggunakan MPI tutorial dengan siswa yang memiliki gaya berpikir sekuensial abstrak dan sekuensial konkret.

Hasil pengujian lanjut di atas, menunjukkan adanya interaksi antara MPI dan gaya berpikir terhadap hasil belajar TPHP siswa SMK Negeri 1 Berastagi. Interaksi MPI dan gaya berpikir dapat ditunjukkan seperti pada Gambar berikut ini:

$$
\mathrm{LP}=\text { Latihan }
$$

\& Praktik

$\mathrm{TL}=$ Tutorial

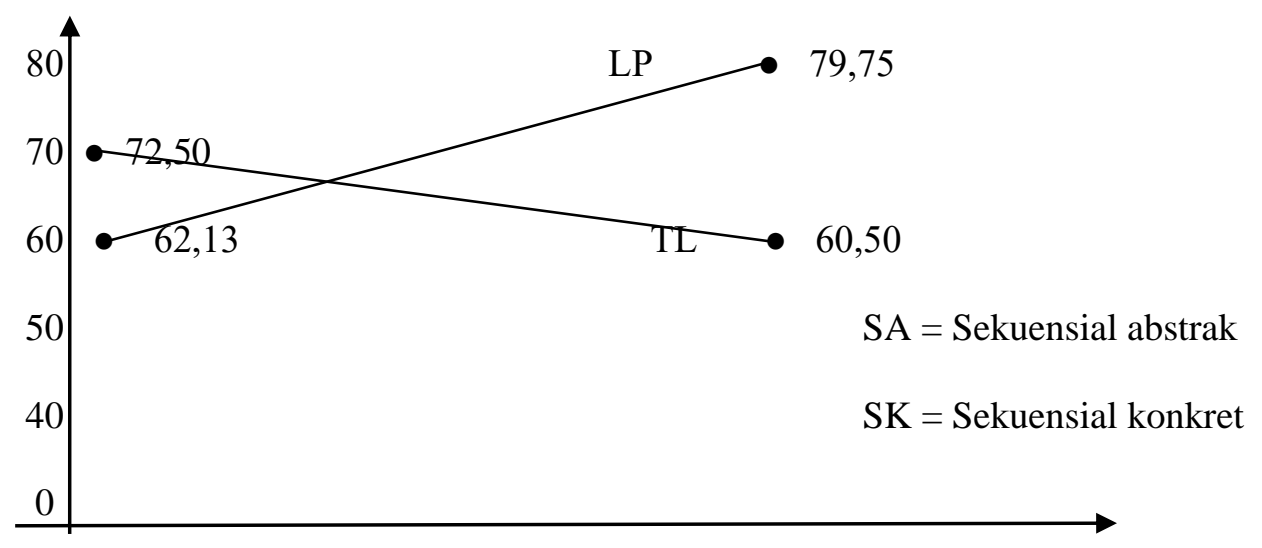

SA

SK

Gambar 1. Interaksi Antara Strategi Pembelajaran Interaktif Berbasis Komputer dan Gaya Berpikir Terhadap Hasil Belajar TPHP

\section{PEMBAHASAN}

Dari hasil pengolahan data yang dilakukan terdapat perbedaan hasil belajar TPHP antara siswa yang dibelajarkan dengan MPI latihan \& praktik dan siswa yang dibelajarkan dengan menggunakan MPI tutorial yaitu rata-rata hasil belajar TPHP siswa yang dibelajarkan dengan menggunakan MPI latihan $\&$ praktik lebih tinggi dibandingkan dengan siswa yang dibelajarkan dengan menggunakan MPI tutorial. Kenyataan ini membuktikan bahwa penggunaan MPI latihan dan praktik lebih baik dalam meningkatkan pengetahuan siswa dalam pembelajaran TPHP daripada penggunaan MPI tutorial. Hal ini beralasan, karena dalam pembelajaran dengan menggunakan MPI latihan dan praktik merupakan pembelajaran yang menekankan pembelajaran yang mampu meningkatkan daya ingat dan bersifat interaktif.

Penggunaan MPI latihan \& praktik dalam pembelajaran TPHP merupakan pembelajaran dengan jalan melatih siswa terhadap bahan pelajaran yang sudah diberikan. Metode dalam pembelajaran ini menanamkan kebiasaan tertentu dalam bentuk latihan. 
Dengan latihan yang terus-menerus diharapkan akan tertanam kebiasaan, kecepatan, ketepatan, kesempurnaan dalam melakukan sesuatu, serta dapat pula dipakai sebagai suatu cara mengulangi bahan latihan yang telah disajikan, juga dapat menambah kecepatan (Rusman, 2009:283).

Pada media pembelajaran interaktif ini, latihan yang diberikan guru dimaksudkan untuk melatih keterampilan siswa dalam melatih keterampilan siswa dalam menggunakan komputer terutama dalam pelaksanaan pembelajaran yang dilakukan. Pada pembelajaran TPHP, mengoperasikan komputer pada media interaktif latihan \& praktik siswa lebih banyak melakukan latihan terhadap bahan pelajaran yang sudah diberikan. Media pembelajaran ini menanamkan kebiasaan tertentu dalam bentuk latihan. Dengan latihan yang terus-menerus diharapkan akan tertanam kebiasaan, kecepatan, ketepatan, kesempurnaan dalam melakukan sesuatu, serta dapat pula dipakai sebagai suatu cara mengulangi bahan latihan yang telah disajikan, juga dapat menambah kecepatan.

Dari penelitian ini diperoleh rata-rata hasil belajar TPHP siswa yang dibelajarkan dengan menggunakan MPI latihan dan praktik lebih tinggi daripada hasil belajar TPHP siswa yang dibelajarkan dengan menggunakan MPI tutorial, meskipun hasil belajar rata-rata siswa antara kedua kelompok tidak terlalu jauh berbeda. Dengan demikian hasil penelitian yang ditemukan sesuai dengan pendapat dikemukakan Sadiman (2003) bahwa media pembelajaran mendukung kegiatan pembelajaran.

Temuan penelitian ini juga mendukung penelitian sebelumnya yang dilakukan oleh George (1982) yang meneliti tentang adanya perbedaan gaya berpikir pada setiap siswa memperlihatkan adanya kecendrungan cara setiap siswa tersebut dalam menerima informasi akan berbeda pula. Penelitian sejenis juga dilakukan oleh Sihombing (2005) yang menunjukkan bahwa perbedaan gaya berpikir siswa dapat mempengaruhi hasil belajar siswa. Di mana dalam simpulan yang diperoleh menunjukkan bahwa hasil belajar matematika siswa yang memiliki gaya berpikir sekuensial abstrak lebih baik dari hasil belajar siswa yang memiliki gaya berpikir sekuensial konkret. Temuan penelitian ini juga mendukung penelitian yang dilakukan oleh Libertus (2006) yang menyimpulkan bahwa gaya berpikir sekuensial abstrak memberikan pengaruh terhadap hasil belajar dan gaya berpikir sekuensial abstrak lebih baik daripada siswa yang memiliki gaya berpikir sekuensial konkret. Penggunaan multimedia sangat mendorong peningkatan hasil belajar siswa dan meningkatkan kemampuan siswa dalam belajar mandiri pada mata pelajaran teknologi pengolahan hasil pertanian siswa sekolah SMK Negeri 1 Berastagi.

Hasil penelitian menunjukkan bahwa rata-rata hasil belajar TPHP siswa yang memiliki gaya berpikir sekuensial abstrak lebih tinggi daripada hasil belajar TPHP siswa yang memiliki gaya berpikir sekuensial konkret. Hal ini mengindikasikan bahwa siswa yang memiliki gaya berpikir sekuensial konkret lebih mampu memahami pelajaran TPHP dibandingkan dengan siswa yang memiliki gaya berpikir sekuensial konkret. Hal ini beralasan, karena: (1) siswa yang memiliki gaya berpikir sekuensial abstrak cenderung berpikir logis, rasional, intelektual dan suka berpikir dalam konsep dan menganalisis informasi. Hal ini sangat sesuai dengan pandangan Latipah (2012) yang menyatakan bahwa realitas bagi para pemikir sekuensial abstrak adalah dunia teori metafisis dan pemikiran abstrak, suka berpikir dalam bentuk konsep, menganalisis informasi. Berbeda dengan siswa yang memiliki gaya berpikir sekuensial konkret, di mana aktivitas berpikirnya berdasarkan kepada realitas dan melalui indera fisik yang mereka miliki saja. Hal inilah yang menyebabkan siswa yang memiliki gaya berpikir sekuensial konkret kurang mampu untuk mengembangkan kemampuan bernalarnya bila dibandingkan dengan siswa yang memiliki gaya berpikir sekuensial abstrak. Orang yang memiliki gaya berpikir sekuensial konkret hanya berpandangan pada kenyataan dan menerima informasi dengan cara teratur, linier dan sekuensial. Realitas dari sekuensial konkret terdiri apa yang mereka ketahui melalui indra fisik, (2) kemampuan untuk menanggapi suatu permasalahan bagi siswa yang memiliki gaya berpikir sekuensial abstrak tampak lebih unggul dibandingkan dengan siswa yang memiliki gaya berpikir sekuensial konkret. Siswa yang memiliki gaya berpikir sekuensial abstrak dalam mengelola informasi cenderung menggunakan peranan akal yang lebih dominan disamping penguasaan atas prinsip, konsep dan generalisasi ataupun pengorganisasian. 
Hal ini sangat sesuai dengan pendapat dari Kaufeldt (2009) yang menyatakan bahwa pemikir sekuensial abstrak dalam mengolah informasi cenderung menggunakan peranan akal yang kuat (logika) di samping penguasaan atas prinsip, konsep dan generalisasi. Maka siswa yang memiliki gaya berpikir sekuensial abstrak sangat cocok dalam belajar matematika, fisika, kosmologi dan astronomi. Sedangkan siswa yang memiliki gaya berpikir sekuensial konkret sangat tergantung akan petunjuk atau prosedur yang lengkap dan teratur dalam menemukan dan memecahkan masalah dalam belajar. Pemikir sekuensial konkret harus mengatur tugas-tugas menjadi proses tahap demi tahap dan berusaha keras untuk mendapatkan kesempurnaan pada setiap tahap. Mereka sangat menyukai pengarahan dan prosedur khusus. Hal ini sangat didukung oleh pandangan DePorter (2005:130) yang menyatakan bahwa pemikir sekuensial konkret dalam menerima informasi cenderung membutuhkan penjelasan dan tujuan yang sangat menyeluruh dari suatu permasalahan.

Berdasarkan uraian di atas, tampak penyebab perbedaan dari hasil belajar teknologi pengolahan hasil pertanian antara siswa yang memiliki gaya berpikir sekuensial abstrak dengan siswa yang memiliki gaya berpikir sekuensial konkret. Temuan penelitian ini sangat sesuai dengan teori-teori yang telah dipaparkan sebelumnya dan memiliki kesamaan dengan hasil penelitian. Temuan penelitian menunjukkan bahwa terdapat interaksi antara MPI dan gaya berpikir terhadap hasil belajar TPHP. Siswa yang memiliki gaya berpikir sekuensial abstrak yang dibelajarkan dengan MPI latihan dan praktik memperoleh hasil belajar TPHP yang lebih tinggi daripada siswa yang memiliki gaya berpikir sekuensial abstrak yang dibelajarkan dengan MPI tutorial.

Demikian pula siswa yang memiliki gaya berpikir sekuensial konkret yang diajarkan dengan menggunakan MPI latihan dan praktik memperoleh hasil belajar TPHP yang lebih rendah dibandingkan dengan siswa yang diajarkan dengan MPI tutorial. Walaupun dalam penelitian ini tidak terdapat perbedaan yang signifikan. Hal ini mengindikasikan adanya interaksi antara MPI dengan gaya berpikir terhadap hasil belajar TPHP siswa. Dapat dijelaskan bahwa: (1) bagi siswa yang memiliki gaya berpikir sekuensial abstrak, maka MPI latihan dan praktik dapat membantu siswa untuk memahami pelajaran secara maksimal, sebab dengan MPI latihan dan praktik sangat sesuai dengan karakteristik siswa yang memiliki gaya berpikir sekuensial abstrak yaitu cenderung ingin mengetahui dan menemukan sebab-sebab dari persoalan. Hal ini sangat sesuai dengan pendapat Ward (2010:133) yang mengatakan bahwa aktivitas favorit pemikir sekuensial abstrak adalah membaca, suka meneliti(ingin mengetahui), serius, sungguhsungguh dan mendalam, maka potensi ini dapat berkembang secara maksimal, namun sebaliknya bagi siswa yang memiliki gaya berpikir sekuensial konkret, MPI latihan dan praktik kurang membantu siswa dalam memahami pelajaran secara maksimal, sebab siswa yang memiliki gaya berpikir sekuensial konkret lebih senang menerima informasi secara teratur, tahap demi tahap dan prosedur yang teratur (2) bagi siswa yang memiliki gaya berpikir sekuensial konkret MPI tutorial lebih membantu siswa dalam mengetahui dan memahami pelajaran, sebab karakteristik siswa seperti ini lebih senang menerima informasi dari orang lain secara teratur, tahap demi tahap dan prosedur yang teratur. Semakin detail informasi yang mereka terima, semakin senang dan semakin baiklah pemahaman mereka.

Meskipun media pembelajaran interaktif tutorial lebih baik digunakan bagi siswa yang memiliki gaya berpikir sekuensial konkret, namun tidak tertutup kemungkinan dapat juga dipakai oleh siswa yang memiliki gaya berpikir sekuensial konkret. Hal ini dikarenakan melalui media interaktif tutorial siswa dapat mengikuti langkah demi langkah materi pembelajaran secara langsung oleh siswa dan secara langsung dapat dipraktikkan oleh siswa itu sendiri. Dan hasil penelitian ini juga menunjukkan bahwa hasil belajar TPHP siswa menggunakan media pembelajaran interaktif latihan dan praktik dan media pembelajaran interaktif tutorial dengan siswa yang memiliki gaya berpikir sekuensial abstak tidak terlalu jauh berbeda, artinya siswa yang memiliki gaya berpikir sekuensial abstrak dapat menggunakan keduanya.

\section{PENUTUP}

Berdasarkan pengolahan data dan pembahasan terhadap hasil penelitian yang dikemukakan sebelumnya maka dlaam penelitian dapat disimpulkan bahwa: (1) Hasil belajar TPHP siswa yang dibelajarkan dengan menggunakan MPI latihan dan praktik lebih tinggi dari hasil belajar TPHP siswa yang 
dibelajarkan dengan menggunakan MPI tutorial; (2) Hasil belajar TPHP siswa yang memiliki gaya berpikir sekuensial abstrak lebih tinggi daripada hasil belajar TPHP siswa yang memiliki gaya berpikir sekuensial konkret; (3) Terdapat interaksi antara penggunaan strategi pembelajaran interaktif berbasis komputer dan gaya berpikir dalam mempengaruhi hasil belajar TPHP siswa. Siswa yang memiliki gaya berpikir abstrak memperoleh hasil belajar TPHP lebih tinggi jika dibelajarkan dengan MPI latihan dan praktik daripada media interaktif tutorial, sedangkan siswa yang memiliki gaya berpikir sekuensial konkret lebih tinggi hasil belajarnya jika dibelajarkan dengan media interaktif tutorial daripada media interaktif latihan dan praktik.

\section{DAFTAR PUSTAKA}

Abdulrahman, M. 1999. Pendidikan Bagi Anak dan Berkesulitan Belajar. Jakarta: Rineka Cipta

Arifin, Zainal. 2012. Pengembangan Media Pembelajaran Aktif dengan ICT. Yogyakarta: Skripta

Arsyad, Azhar. 2002. Media Pembelajaran. Jakarta: Raja Grafindo Persada

Ausubel.1963. The Psycology of Meaningful Verbal Learning. New York: Grune and Straton

Bachtiar, Harsja. 2012. Media Pendidikan. Depok: Rajawali Press

Bloom, B.S. 1976. Human Characteristics and School Learning. New York: Mc Graw Hill.

Bruner, J.S. 1973. Beyond The Information Given. New York: W.W.Norton

Dahar, Ratna Wilis. Teori-Teori Belajar dan Pembelajaran. 2006. Jakarta: Erlangga

Delons, Jacques. 2001. Pendidikan Untuk Abad 21. Jakarta: Departemen Pendidikan Nasional

DePorter, Bobbi. 1999. Quantum Learning (terjemahan). Bandung: Yodkali

Dick,W \& Carey, L. 1985. The Systematic Design Of Instructional. Glenview: Scott, Foresman

Dimyanti dan MUdjiono. 2002. Belajar dan Pembelajaran. Jakarta: Rineka Cipta

Dwiari, Rini. 2008. Teknologi Pangan Jilid 1. Klaten: Macana Jaya Cemerlang

Gagne, R.M. 1999. The Conditioning of Learning. New York: Holt, Rinehart andWinston
Hamdani. 2011. Strategi Belajar Mengajar. Bandung: Pustaka Setia

Hamid, Abdul. 2007. Teori Belajar dan Pembelajaran. Medan.: Pasca Sarjana Unimed

Hutagalung, Taher. 2002. Evaluasi Pengajaran. Medan: Universitas Negeri Medan

Kaufeldt, Martha. 2009. Berawal Dari Otak. Jakarta: Indeks

Latipah, Eva. 2012. Pengantar Psikologi Pendidikan. Yogyakarta: Pedagogia

Miarso, Yusuf Hadi. Satuan Tugas Definisi dan Terminologi AECT (terjemahan) 1986. Jakarta: Rajawali

Panen, P. dkk. 2003. Pemanfaatan Teknologi Informasi dalam Peningkatan Mutu Pembelajaran Bahasa Indonesia, Ilmu Pendidikan, (online), Vol. 16, No.1 (http://www.depdiknas.go.id)

Pedagogia dan Terminologi AECT (terjemahan). 1986. Jakarta: Rajawali Press

Prastowo, Andi. 2012. Pengembangan Sumber Belajar. Yogyakarta:

Romiszowski. 1981. Designing Instructional System. New York: Nicolas

Rusman. 2012. Pembelajaran Berbasis Teknologi Informasi dan Komunikasi. Jakarta: Rajawali Press

Sanjaya, Wina. 2008. Perencanaan dan Desain Sistem Pembelajaran. Jakarta: Kencana

Seels, Barbara. 1994. Teknologi Pembelajaran (terjemahan). Jakarta: UNJ

Siregar, Eveline. 2004. Mozaik Teknologi Pendidikan. Jakarta: Kencana

Siregar, Eveline. 2010. Teori Belajar dan Pembelajaran. Bogor: Ghalia Indonesia

Sukiman. 2011. Pengembangan Media Pembelajaran. Yogyakarta: Pedagogia

Suparman, Atwi. 2012. Desain Instruksional Modern. Jakarta: Erlangga

Ward, Hellen. 2007. Pengajaran Sains Berdasarkan Cara Kerja Otak. Jakarta: Indeks

Wena, Made. 2011. Strategi Inovatif Kontemporer. Jakarta: Bumi Aksara 